\title{
A critical review of sustainable built environment development in Iran
}

1 Ahmadreza Hakiminejad BArch, MA, PGC PhD Candidate, Department of Built Environment, School of Computing and Technology, University of West London, London, UK

2 Changfeng Fu MEng, MPhil, PhD, MRTPI, MCIAT

Associate Professor, Department of Built Environment, School of

Computing and Technology, University of West London, London, UK
3 Hamideh Mohammadzadeh Titkanlou BSC, MA, PhD Member of Managerial Board, Andisheh New Town Development Company, Tehran, Iran
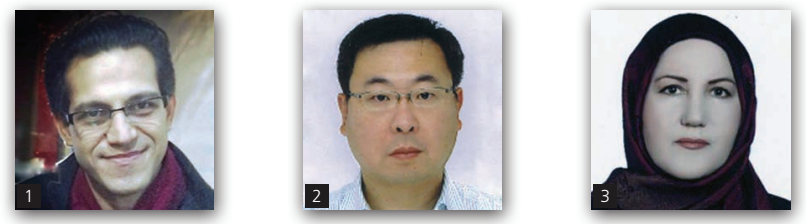

Population explosion, irresponsible consumerism, environmental catastrophes, tremendous market-based urban development and the dedication of cities to cars and concrete rather than citizens and environment has put a big question mark over the future of the world's developing countries. Urban sustainability has emerged as the only solution to the environmental, social and economic challenges facing our cities. In recent years in countries struggling with the concept of urban sustainability, such as Iran, academic circles and the state have had heated debates over sustainable development. The purpose of this paper is to examine the current situation of sustainable development of the built environment in Iran. The focus is on recognition of urban governance, policies and regulations. The paper examines the scope of sustainable technologies employed in Iran in terms of the development of energy efficiency and renewable energies. This is followed by an investigation of urban sustainability assessment methods through which the paper tackles policy, technology and assessment mechanism issues from a perspective of sustainable built environment development in both theoretical research and practical development in Iran.

\section{Introduction}

Warning bells have already rung and the necessity for 'urban sustainability' has been highlighted all over the world. Developing countries - more specifically, cities in developing countries - are in an even more critical condition. In 2013, eight of the top ten most populated cities in the world were located in developing countries (UN, 2014) and there is a big question mark hanging over the future of the world's developing countries due to population explosion, irresponsible consumerism, environmental pollution, market-based urban development and the focus of cities on cars and concrete rather than their citizens and environment.

Under the umbrella of 'green' politics in western countries in the 1970s, the first international gathering, the United Nations (UN) conference on the human environment, took place in Stockholm in 1972 to consider the global ecosystem and environment (Mulvaney, 2011). This movement was followed by significant global conferences in the late twentieth century to unite countries around the world to pursue sustainable development together. Since the early 1990s, debates over 'sustainable cities' have been raised among theorists, scientific and academic circles, architects, urban planners and governmental and non-governmental organisations (NGOs). Iran took this into consideration by establishing the Iranian National Committee on Sustainable Development (NCSD) in 1993, just one year after the UN conference on environment and development, which led to one of the most important sustainability manifestoes: Agenda 21 (Latifian et al., 2014).

Cities have turned into the world's largest energy consumers (buildings consume approximately $40 \%$ of the world's produced energy) and also account for $24 \%$ of global carbon dioxide emissions (CCSD, 2014). In Iran, $97 \cdot 2 \%$ of domestic consumption of primary energy originates from petroleum (44.8\% from oil and 52.4\% from gas) (Sabetghadam, 2006). The oil-based economy of Iran has collapsed over the past 2 years due to massive US-led sanctions, which have drastically affected the rate of Iran's oil export. Nevertheless, Iran remains the fifth largest oil exporter of the Organization of the Petroleum Exporting Countries (Opec) and holds the fourth largest oil reserves and 
second largest natural gas reserves in the world (Moshiri, 2012). Today petroleum products comprise more than $80 \%$ of the country's export.

Concerning geographical features, Iran is located in a semi-arid region of the Middle East with high levels of sunshine duration and low average annual precipitation ( $252 \mathrm{~mm} /$ year), ranging from less than $50 \mathrm{~mm} /$ year in central Iran to around $1000 \mathrm{~mm} /$ year on the Caspian Sea coastline (Alizadeh and Keshavarz, 2005; Tabari et al., 2012). Despite the fact that Iran has a diverse climate from cold winters to hot summers, it is worth noting that $25 \%$ of the country's land area is covered by two salt deserts that lie within the centre of a plateau (Foy, 2001) and more than $85 \%$ of its land area is considered to be arid or semi-arid (Madani, 2014).

In developing countries such as Iran, public awareness of the term urban sustainability is quite limited. Even among governmental bodies, developers and stakeholders there is a serious and often obvious lack of concern towards sustainable development. This is clearly a major challenge for sustainable development in Iran. According to the Statistical Centre of Iran, more than $70 \%$ of the country's population lived in cities in 2011 (SCI, 2013). In Tehran, the population has risen more than fivefold over the last 50 years (AoTM, 2014). The complexity of urban governance and decisionmaking processes, social inequality coupled with a vast gap between rich and poor, an inefficient public transport system and massive environmental pollution are just some of the major challenges faced by Iranian cities today.

The aim of this paper is to investigate the current situation and experience of sustainable urban development in Iran in terms of

- governmental administrative framework, policies, legislation and regulations

- the application and development of energy efficiency and renewable technologies

- sustainability assessment mechanisms and tools.

The review is also associated with a comparison of the relevant issues in the UK and other countries. The major research method implemented for this study was a literature review, supplemented by observations from semi-structured interviews with a range of relevant senior officials, academics and industrial practitioners in urban planning and construction.

\section{Policies and legislation for sustainable urban development}

\subsection{The hierarchical structure of the administration} system

The emergence of Iran's institutional structure for urban management dates back to 1907, one year after the 'constitutional revolution' (Tehran Municipality, 2014). Although the national parliament (Majlis) passed the City Council Law on 2 June 1907, the first 'baladieh' (municipality) was not established until 1910
(Vahdat Zad, 2011). A century later, in 2010, there were 1113 municipalities around the country (MoI, 2010).

Five-year development plans define the planning system at national level (Tajbakhsh, 2005), with the Ministry of Roads and Urban Development (RUD) and the Ministry of Interior (MoI) the top governmental authorities who set planning legislation at national level. As one of the most important governmental bodies dealing with urban planning and development, the Management and Planning Organization (MPO) was shut down in July 2007 by order of Iran's former president, Mahmoud Ahmadinejad (Firouz, 2010); however, the newly elected president, Hassan Rouhani, ordered the revival of the MPO in late 2014. Alongside the MPO, the Higher Council of City Planning and Architecture, the 'Clause 5' Committee of the City Planning Council, the Provincial Office of the RUD, provincial governors including the provincial governor's technical advisor, the Provincial Development and Planning Council, the Provincial City Planning Council and the County Planning Committee are all involved in the decision-making process of urban planning and development (Tajbakhsh, 2005). There are also some other constituents in the decision-making process, including MPs, the private sector, civil society organisations and other governmental agencies such as the military with a stake in the process (Tajbakhsh, 2005).

As heads of municipalities, mayors play a very critical role in both central government and city councils. In relationship with central government, the mayor is under pressure from a centralised hierarchical system and the municipality acts as a 'branch of the central government' rather than an independent role player (Madanipour, 2006). On the other hand, the relationship between the city council and the mayor is also a politically charged one. In Iran, a mayor is not elected democratically, but any Iranian citizen can participate in the mayoral election indirectly through the electoral city council, which recommends candidates and elects the mayor (Rezazadeh, 2011). Due to the force of democratic decentralisation in 2006, elected local advisory councils have been set up as local authorities at the neighbourhood level (Hafeznia and Veicy, 2009).

\subsection{Sustainable urban development control}

Iran's Department of Environment (DoE) was officially established in 1971 to oversee environmental preservation. After the Islamic revolution in 1979, Article 50 of the new constitution recognised (Khosravi, 1987)

\footnotetext{
... a public duty to protect the environment so that the present and future generations are to have a thriving social life. Thus, any form of activity, whether economic or otherwise, that causes pollution of and irreparable damage to the environment, is prohibited.
}

Despite the establishment of the DoE, the first influential step towards sustainable development in Iran dates back to the post Iran-Iraq war period in the early 1990s, just a year after the Rio Earth Summit in 1992, when the Iranian NCSD was established by the DoE. Since then, environmental sustainability has turned into a 


\section{Offprint provided courtesy of www.icevirtuallibrary.com Author copy for personal use, not for distribution}

critical discourse in Iran among green NGOs and activists as well as governmental bodies. In the capital city, Tehran, a committee dedicated to the environment was established by Tehran City Council alongside an Environmental and Sustainable Task Force set up by Tehran Municipality in 2003, headed by the mayor's special advisor (Madanipour, 2011). The 682-page Green Workbook was published in 2007 by the committee, which defined the municipality's policies and activities to promote environmental sustainability (Tehran Municipality, 2007). In addition, the Tehran New Detailed Plan - a strategic document for urban management that was revised and approved by the higher council of town planning and architecture in 2007 - outlines the prospects for sustainable development (Andalib et al., 2010).

The Iranian NCSD includes 13 sub-committees covering climate change, jungle and forest principles, biological diversity, rural sustainable development, education, green production and efficiency, urban sustainable development and management and so on. The committee has held 199 commissions since its establishment (DoE, 2013). After the UN conference Rio+20 held in June 2012, the NCSD started to set up a redevelopment and amendment plan for its fundamental structures. Multiple official authorities such as ministries and governmental departments were involved in this committee in the early days but, from an organisational point of view, it is still questionable whether the NCSD, under the shadow of the DoE, spontaneously concentrates more on the environmental aspects of sustainable development than on social and economic concerns.

\section{Sustainable technologies}

In recent years, Iran has suffered heavily from a water crisis due to government mismanagement, irresponsible consumption and certain environmental phenomena that led to groundwater depletion and extra pressure on water resources (Madani, 2014). Furthermore, a noticeable increase in energy consumption over recent decades in Iran (World Bank, 2011) confirms the necessity of employing sustainable technologies such as renewable energies and energyefficient methods and techniques.

\subsection{Energy efficiency}

The first Sustainable Energy Watch (SEW) for Iran was launched in 2005 under the terms of an agreement between the Institute for International Energy Studies, the Iranian Ministry of Petroleum and Helio International, an NGO based in Paris (Sabetghadam, 2006). The research was developed based on eight SEW indicators using 1990 data; according to indicators' benchmarks, a value of 1 is considered for either the global average or the historical trend for Iran, while the sustainability target is determined by a value of 0 . As the results demonstrate (see Table 1), the indicator considered for 'access to electricity' is the closest to the sustainability target. Although not satisfactory, some minor improvements have been observed regarding investment in clean energies as well as the proportion of renewable energies in total primary energy use. According to the research, there has been deterioration in sustainability for indicators related to environmental pollutants and energy intensity (Sabetghadam, 2006).

\subsubsection{Energy efficiency in the building sector}

The building sector is the largest energy consumer in Iran. According to a Ministry of Energy report (MoE, 2008), residential and commercial buildings were responsible for about $41 \%$ of the country's energy consumption in 2006 , while both industry and transport sectors shared less than $50 \%$ of energy consumption in the same year. The average rate of energy consumption in the building sector in Iran is reported to be 2.58 times higher than the world's average energy use (Tabatabaei et al., 2013). There is therefore a need for a reduction and better management of energy use in the building sector in both existing and new developments. In recognition of the importance of reducing worldwide primary energy consumption, Iran founded various governmental organisations in 1995 to research energy conservation methods and renewable energies (Nasrollahi, 2009a; Nasrollahi et al., 2013), the most notable of these being the Iranian Fuel Conservation Company (IFCO), Iran Energy Efficiency Organization (IEEO) and Iran Renewable Energy Organization (Suna). Following the setting up of these institutions, Iran defined some strategies and plans to reduce the country's energy consumption, including that consumed by buildings. These measures include the

\begin{tabular}{|c|c|c|c|c|}
\hline \multirow[b]{2}{*}{ Indicator } & \multicolumn{2}{|c|}{ Data points } & \multicolumn{2}{|c|}{ Result } \\
\hline & $X$ (current) & $X(1990)$ & I (current) & / (1990) \\
\hline Carbon dioxide emissions: kgC/cap & 1555 & 1010 & $1 \cdot 486$ & $0 \cdot 848$ \\
\hline Ambient pollutant: \% & $38 \cdot 80$ & $18 \cdot 40$ & $2 \cdot 386$ & $1 \cdot 000$ \\
\hline Access to electricity: \% & $96 \cdot 70$ & $82 \cdot 80$ & 0.033 & $0 \cdot 172$ \\
\hline Investment in clean energy: \% & $0 \cdot 20$ & - & 0.998 & 1.000 \\
\hline Vulnerability: \% & $80 \cdot 00$ & $85 \cdot 80$ & $0 \cdot 800$ & 0.858 \\
\hline Public sector investment: \% & $11 \cdot 60$ & $11 \cdot 60$ & $1 \cdot 157$ & $1 \cdot 157$ \\
\hline Energy productivity: $\mathrm{MJ} / \$$ & $22 \cdot 60$ & $20 \cdot 60$ & $2 \cdot 248$ & $2 \cdot 040$ \\
\hline Renewables: \% & $2 \cdot 00$ & $1 \cdot 00$ & 1.077 & 1.088 \\
\hline
\end{tabular}

Table 1. Sustainable Energy Watch (SEW) for Iran, reproduced by authors (Sabetghadam, 2006) 


\section{Offprint provided courtesy of www.icevirtuallibrary.com} Author copy for personal use, not for distribution

introduction of national building regulations for energy savings in buildings (Code 19) and an increase in energy prices (Nasrollahi et al., 2013).

\subsubsection{Energy-efficient urban and architectural design}

Because of very low energy costs in Iran, there has been little interest in energy-efficient buildings in recent decades, but social interest in low-energy buildings has slightly increased since the reduction in energy subsidies in 2010. Due to the high cost of energy-efficient building technologies such as insulation materials and renewable energy systems, there is a lack of interest in using these techniques; the application of cost-neutral energy saving methods is therefore essential. Architectural methods to reduce energy consumption are achieved purely through intelligent design and only rarely increase building costs (Nasrollahi et al., 2013). Poor architectural design that does not take climate conditions into consideration is one of the main causes of high-energy consumption in buildings. A comparative study on heating and cooling energy use in two buildings within the same contextual conditions with similar materials but different architectural designs revealed that a suitable architectural design can reduce energy consumption by almost 48\% (Nasrollahi, 2009b).

The geographical and geological situation of Iran depicts a country in a stressed climate. In most parts of the country, heat and dryness of air and soil have prevailed for centuries, which is why wind, water and the sun have played significant roles in traditional Iranian architecture and urban planning. Environmentally responsive architecture and urban planning in older Iranian cities led to a series of logical solutions to aid human comfort (Eiraji and Akbari Namdar, 2011). At the urban level, the city network, street patterns and urban structure orientation in older Iranian cities such as Kerman, Isfahan and Yazd (Figure 1) were shaped based on geographical and climatic features such as wind direction and sun exposure (Arjomand Kermani and Luiten, 2009), and the spatial morphology of these cities is compact and dense (Figure 2). It is considered that the application of appropriate urban form, type of construction, spatial distribution of land use and optimal density can reduce energy consumption in urban environments (Owens, 1991). The compact nature of both the urban fabric and individual buildings in older Iranian cities minimises heat gain in summer and heat loss in winter, therefore leading to reduced energy needs for cooling or heating. Such a design also allows for a very noticeable reduction in the whole infrastructure network and transportation system (NematiMehr, 2008).

Wind, as a natural cooling system, was widely used in traditional Iranian buildings and the use of wind energy in Iran dates back to the ancient era (17th century BC) (Asadi Asad Abad et al., 2012). According to historical references, windmills were used to grind seeds and pump water (Asadi Asad Abad et al., 2012). Climateresponsive architectural methods employed in Iranian traditional buildings such as badgir (wind catchers), courtyards, hozkhaneh (places in the lower ground floor with a pond), ivaan (verandas), Shabestan (a vaulted columned space in the Iranian traditional mosques), sabaat (passages) and so on are iconic architectural and urban elements. Badgir - vertical shafts that bring prevailing wind into a building - and courtyards are the most characteristic features of Iranian vernacular architecture and have long played a key role in the natural ventilation of residential buildings (Soflaee and Shokouhian, 2005). Regarding the utilisation of water resources in cities in the past, qanats (Figure 3 ) were created as a water management system used to supply water for both human settlements and irrigation purposes. Iran is home to the oldest and largest known qanat in the world, which has been situated in the city of Gonabad in the eastern part of the country for almost 2700 years. It still provides drinking and agricultural water to nearly 40000 people. Its mother well is about $360 \mathrm{~m}$ deep and it stretches $45 \mathrm{~km}$ underground (Arjomand Kermani and Luiten, 2009). Traditional building structures such as the abanbar (water reservoir) and yakhchal (icehouse) combine splendid architectural functionalism with magnificent formal expression in the urban context (Ahmadkhani Maleki, 2011).

Undoubtedly, learning from the past has the potential to inspire architects and planners by taking geographical and climatic features into account. The intelligent use of natural ventilation at urban and architectural levels through the use of courtyards, roof gardens and even creatively designed wind catchers, particularly in new developments, can restore environmentally friendly relations between human beings and nature.

\subsubsection{Heavy thermal mass materials}

In the traditional architecture of Iran, particularly in warm dry regions (which is the prevailing climate in Iran), wall types were commonly made of a mixture of unfired clay, mud and straw or brick, and were 50-60 cm thick (Mohammad and Shea, 2013). The significant role of these materials in providing thermal comfort in traditional buildings has been recognised. Mohammad and Shea (2013) evaluated the thermal performance of modern wall types commonly used in new residential buildings in Iran. According to this study, traditional materials are increasingly being replaced by more slender construction walls mostly made of hollow clay blocks (HCBs), lightweight expanded clay aggregate (LECA) blocks and autoclaved aerated concrete (AAC) blocks (Table 2), with the HCB reported to be the most popular choice in practice. Some experts prefer using LECA blocks due to a perceived performance advantage in thermal damping, while the use of AAC blocks is less common due to some implementation difficulties. The results of this study also showed that the application of LECA combined with insulation in place of normal LECA resulted in about 52\% total energy savings.

\subsection{Renewable energy}

Following the energy crisis in the 1970s, some developed countries decided to invest heavily in the development of renewable energies. Recent research shows that the global spend on renewable energies in 2010 was US $\$ 243$ billion - a rise of $30 \%$ on the year 2009 (Sharifi and Shabanikia, 2012). Following worldwide interest in the subject, as noted earlier, Suna was established in 1995 for the purpose of assembling updated information and technology in connection with the utilisation of renewable energy resources, the measurement 


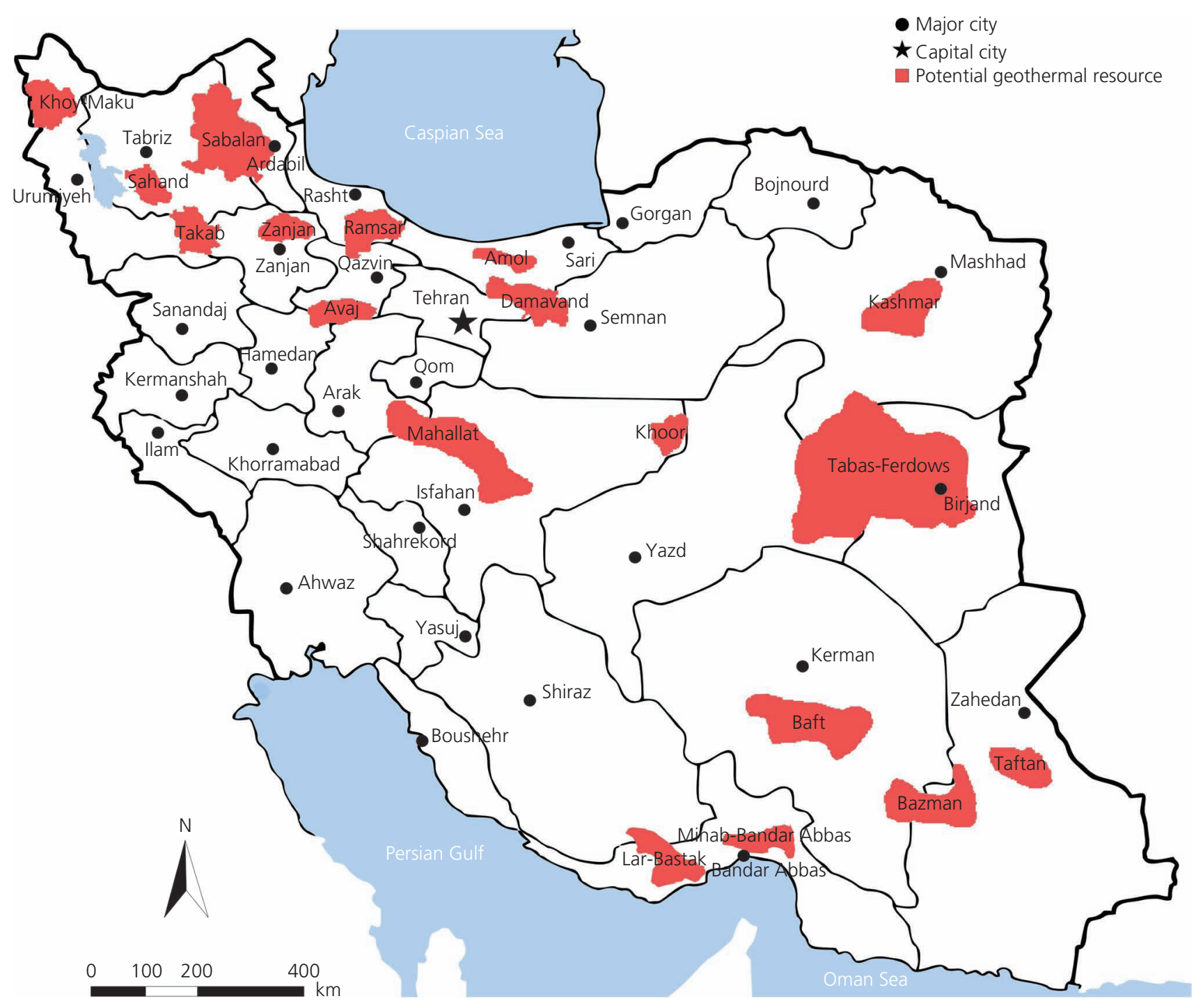

Figure 1. Geothermal resources map of Iran, reproduced by authors (Noorollahi et al., 2009)

of potentials, and the execution of solar, wind and geothermal, hydrogen and biomass projects (Sharifi and Shabanikia, 2012).

\subsubsection{Wind energy}

In cooperation with Moshanir Company and by order of Suna, the potential of wind speed over the whole country was calculated by the German company Lahmeyer International. According to this research, the wind power capacity in Iran was estimated to be around $100000 \mathrm{MW}$, clearly demonstrating the huge potential for the development of wind farms (Asadi Asad Abad et al., 2012). In terms of installed wind power capacity, Iran is ranked 51 out of 103 in the world (WWEA, 2014). Based on statistics obtained from Suna, currently $94 \mathrm{MW}$ of electricity is being produced by existing wind power plants across the country. Manjil wind farm (Figure 4), the largest wind power plant located in Gilan, north Iran, uses 111 turbines with capacities ranging from $300 \mathrm{~kW}$ to $660 \mathrm{~kW}$.
The design and manufacture of wind turbines in Iran has been developing since 2008 as Suna introduced research projects with the aim of localising the production of different parts of wind turbines (Figure 5) (Sharifi and Shabanikia, 2012). According to information published by Suna, Iran presently has the technology to manufacture $35 \%$ of the inner parts of wind turbines, and Suna is also trying to encourage private sector investment in wind farms.

\subsubsection{Solar energy}

Average solar radiation in Iran is about $19 \cdot 23 \mathrm{MJ} / \mathrm{m}^{2}$ and is even higher in the central part of the country. Calculations show that the amount of useful solar radiation hours in Iran exceeds $2800 \mathrm{~h} /$ year (Kazemi Karegar et al., 2005). The first photovoltaic (PV) site, with a capacity of $5 \mathrm{~kW}$ DC, was established in central Iran in Doorbid village near Yazd in 1993. The second PV site, with $27 \mathrm{~kW} \mathrm{AC}$ capacity, was installed in 1998 in the villages of Hosseinian and 


\section{Offprint provided courtesy of www.icevirtuallibrary.com Author copy for personal use, not for distribution}

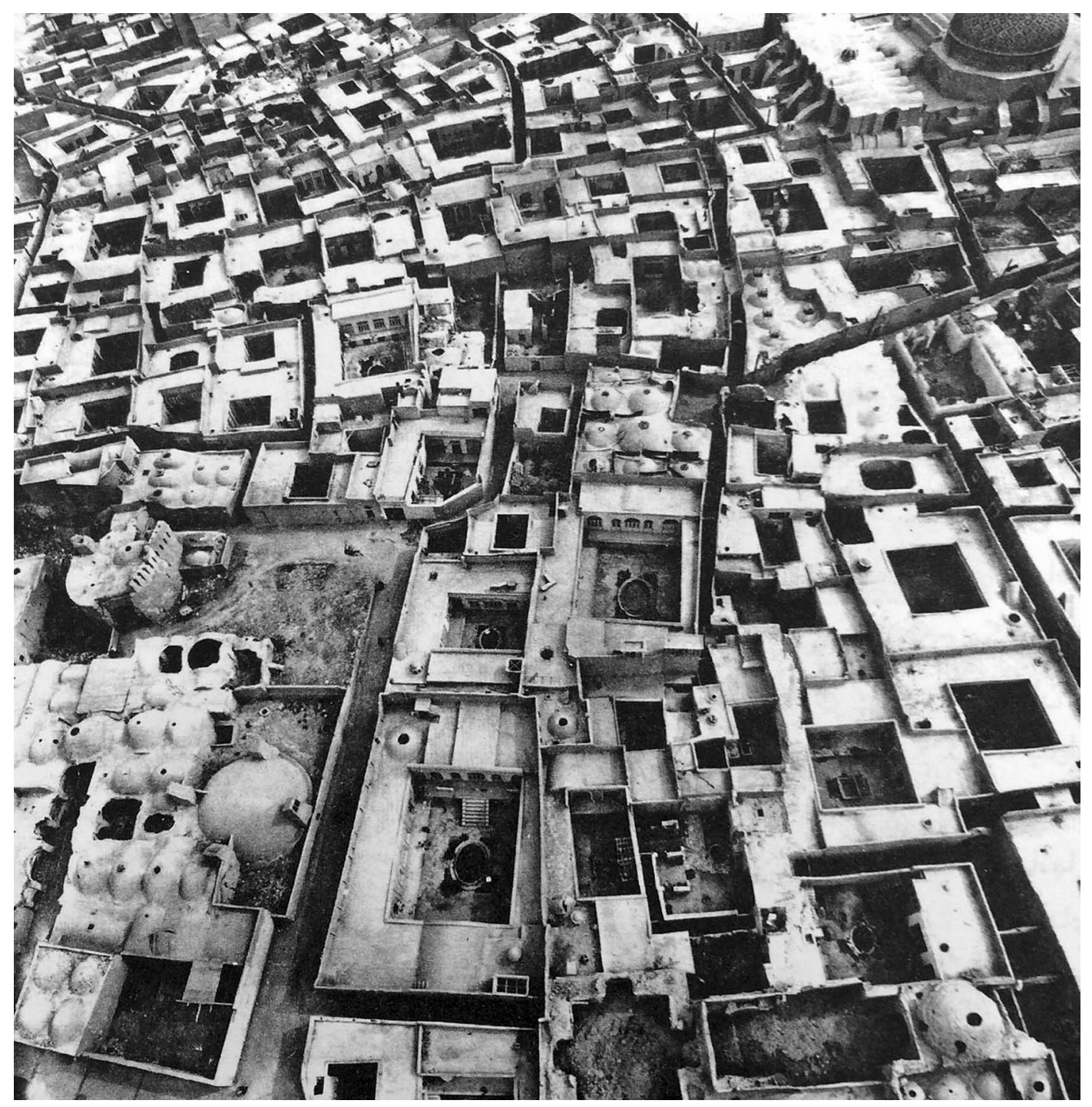

Figure 2. Urban form: Yazd old city (Tavassoli, 2011)

Moalleman in Semnan, $450 \mathrm{~km}$ from Tehran. It is worth mentioning that all the equipment on these sites was made in Iran. However, using solar energy to produce electricity in Iran is not very popular and the cost of these types of sites is relatively high at about US $\$ 3500 / \mathrm{kW}$. There are, however, some projects designed to use solar energy combined with a thermal power plant to produce electrical energy (Kazemi Karegar et al., 2005). According to research implemented by DLR (a government institute based in Germany), Iran has an area of $2000 \mathrm{~km}^{2}$ with high potential for the installation of solar power plants for $60000 \mathrm{MW}$ electricity production (Suna, 2012b). Alongside two established solar power plants in Shiraz (Figure 6) and Yazd, Suna has defined several research and development projects in cooperation with public and private sectors. The variety of projects ranges from feasibility studies to implementation, construction and utilisation. For instance, research conducted in cooperation with DLR aims to produce a solar map of Iran to show measurements of potential and to specify both the locality and capacity of proposed solar-thermal power plants (Suna, 2012b). Practical research such as the design and implementation of PV street lights, tunnel lighting and pumps for agricultural purposes has also been considered. It seems that solar village projects are becoming popular for the state due to the very high cost of conventional power plants for remote rural areas. By 2010, 634 rural households in Iran were receiving electricity derived from solar power (SABA, 2010). It should also be mentioned that the energy generated by solar power in Iran was $53 \mathrm{MW}$ in 2005 and $67 \mathrm{MW}$ in 2011 (Kazemi Karegar et al., 2005).

\subsubsection{Geothermal energy}

Geothermal energy development in Iran was initially started by James R. McNitt, one of the UN experts who visited Iran in 1974 and reported that Iran had very promising prospects for geothermal energy development (Fotouhi, 1995). Upon his recommendation, in 1975, a contract between the Ministry of Energy and ENEL of Italy 


\section{Offprint provided courtesy of www.icevirtuallibrary.com Author copy for personal use, not for distribution}

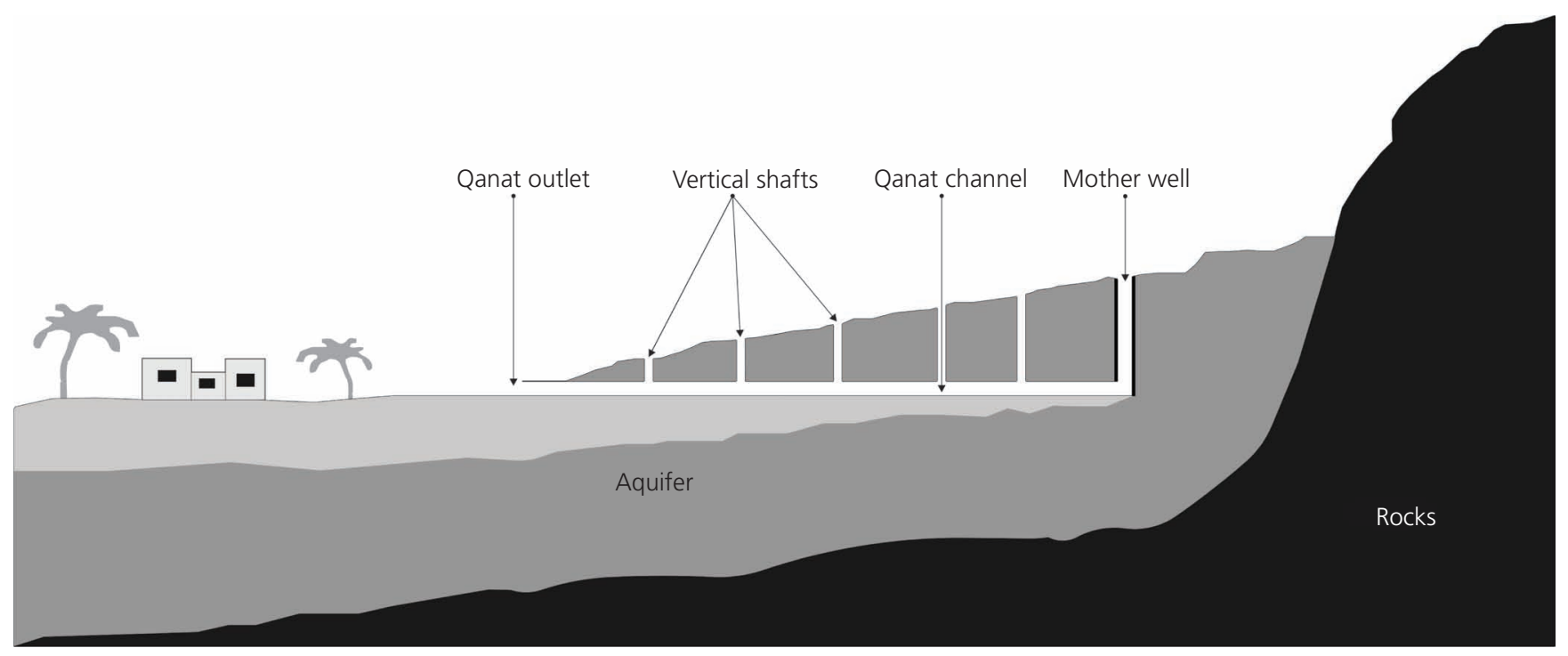

Figure 3. General schematic illustration of a qanat system, reproduced by authors (Taghavi Jeloudar et al., 2013)

in association with Tehran Berkeley of Iran was signed for the geothermal exploration of an area covering $260000 \mathrm{~km}^{2}$ in the northern part of the country. A nationwide geothermal potential survey project carried out by Suna from 1995 to 1998 suggested ten more prospective geothermal areas in other parts of the country. These areas were assumed to possess reasonable potential and were recommended for power generation and immediate utilisation purposes (Fotouhi and Noorollahi, 2000). A new updated and more accurate digital map of Iran detailing potential geothermal sites using a geographic information system was developed at Kyushu University in 2007. The results indicated $8.8 \%$ of Iran's land area as having potential for geothermal energy in 18 promising fields (Figure 1) (Noorollahi et al., 2009). However, Meshkinshahr geothermal power plant, located in north west Iran and with a capacity of $55 \mathrm{MW}$, is the only operational geothermal power station in the country (SABA, 2010).

\subsubsection{Energy from biomass}

In 2004, the first potential measurements of biomass were carried out in Iran in the cities of Shiraz and Mashhad, and the first biomass power plant was established in Shiraz in 2009. Ongoing biomass developments led to the establishment of three other power plants in Mashhad (in 2010), Tehran (in 2012) and Sari (in 2012) (Suna, 2012a). According to research carried out by DLR, the potential of the development of biomass in Iran is estimated to reach 3390 MW by 2050 (Suna, 2012a). Generally speaking, the circular metabolism of the biomass system, which obtains energy from waste, is considered to be very sustainable and environmentally friendly.

\section{Sustainability assessment methods and technologies}

Sustainable development has become one of the most controversial and leading topics in many research fields. Despite agreement on the main elements of sustainable development, methods for sustainability measurement still remain a key challenge in both research and practice. The purpose of such an assessment is more about discovering methods for improvement rather than judgement of the subject (Badri and Eftekhari, 2003). The term sustainability assessment is applied in two different contexts. Firstly, it is used to assess the lifecycle performance of existing buildings and communities. Secondly, it is used to identify the evaluation of sustainability measures considered for forthcoming projects at pre-implementation stages (Devuyst, 2000).

In 1979, Iran's DoE designated the Environmental Assessment Bureau (EAB) very limited activity, such as site selection for development projects (Nanbakhsh, 1993). A year later, in 1980, the EAB merged with the Environmental Research Office due to a shrinking of organisational structure. In 1987, the EAB began its activities again in establishing a new framework based on environmental impact assessment (EIA) principles (DoE, 2013). In 1995, EIA was mandated by the High Council for Environmental Protection (HCEP) to be employed in some specific industrial and large-scale projects in 33 categories, including petrochemical plants, refineries, power plants, tourism and eco-tourism sites, mining, steel industries, dams and irrigation, rails and roads, airports, waste sites and landfills, industrial parks and so on. (DoE, 2013). In 2000, environmental assessment was defined in Article 105 of the Third Development Plan: 'all large scale production and service-providing projects must, in the process of the feasibility study and before execution, be assessed from the standpoint of their impact on the environment, on the basis of the criteria that will be proposed by the HCEP and approved by the Cabinet' (Rahbar, 2005).

Due to the fact that sustainability indicators play the main role in the evaluation of urban sustainability, Iran's DoE, in cooperation with some ministries and governmental organisations, under the leading 


Construction materials
$\begin{aligned} & \text { Claster lining }(3 \mathrm{~cm}) \\ & \text { Sand and cement mortar }(3 \mathrm{~cm}) \\ & \text { Exterior stone finishing }(2 \mathrm{~cm})\end{aligned}$
$\begin{aligned} & \text { Plaster lining }(3 \mathrm{~cm}) \\ & \text { Cland block }(15 \mathrm{~cm} \text { with } 2 \mathrm{~cm} \text { expanded polystyrene (EPS)) } \\ & \text { Exterior stone finishing }(2 \mathrm{~cm})\end{aligned}$
Plaster lining $(3 \mathrm{~cm})$
LECA block $(20 \mathrm{~cm})$
Sand and cement mortar $(3 \mathrm{~cm})$
Exterior stone finishing $(2 \mathrm{~cm})$
Plaster lining $(3 \mathrm{~cm})$
LECA block $(10 \mathrm{~cm})$
Cavity filled $\mathrm{EPS}(5 \mathrm{~cm})$
LECA block $(10 \mathrm{~cm})$
Sand and cement mortar $(3 \mathrm{~cm})$
Exterior stone finishing $(2 \mathrm{~cm})$
Plaster lining $(3 \mathrm{~cm})$
AAC block $(20 \mathrm{~cm})$
Sand and cement mortar $(3 \mathrm{~cm})$
Exterior stone finishing $(2 \mathrm{~cm})$
Plaster lining $(3 \mathrm{~cm})$
AAC block $(10 \mathrm{~cm})$
Cavity filled with EPS $(5 \mathrm{~cm})$
AAC block $(10 \mathrm{~cm})$
Sand and cement mortar $(3 \mathrm{~cm})$
Exterior stone finishing $(2 \mathrm{~cm})$

Table 2. Categorisation of conventional wall types, reproduced by authors (Mohammad and Shea, 2013)

lights of the NCSD, developed 26 national environmental indicators within five categories and 13 sub-categories (DoE, 2014)

- climate (climate change and air quality)

- water (water quality and water quantity)

- land (desertification, forests and agriculture)

- biodiversity (ecosystem, coasts and seas, and species)

- production and consumption patterns (raw materials, energy consumption and waste management).

The indicators were developed in the light of Iran's local conditions based on three international guidelines - the environmental performance index, the UN Commission on Sustainable Development and the Millennium Development Goals. Although the indicators have been approved by the NCSD, approval from parliament is still awaited.

With regard to the development of social indicators, Tehran Municipality introduced a local version of socio-cultural impact assessment known as ATAF in 2006 (Tehran Municipality, 2013), which has led to the Neighbourhoods Profile project being implemented in some of Tehran's communities and localities. The most recent social indicators developed by the Socio-cultural Deputy of Tehran Municipality include four categories, 31 indicators and 219 objectives as follows.

Distribution and dispersion (10 indicators): housing; food, services and consumer goods; healthcare; education; cultural- 


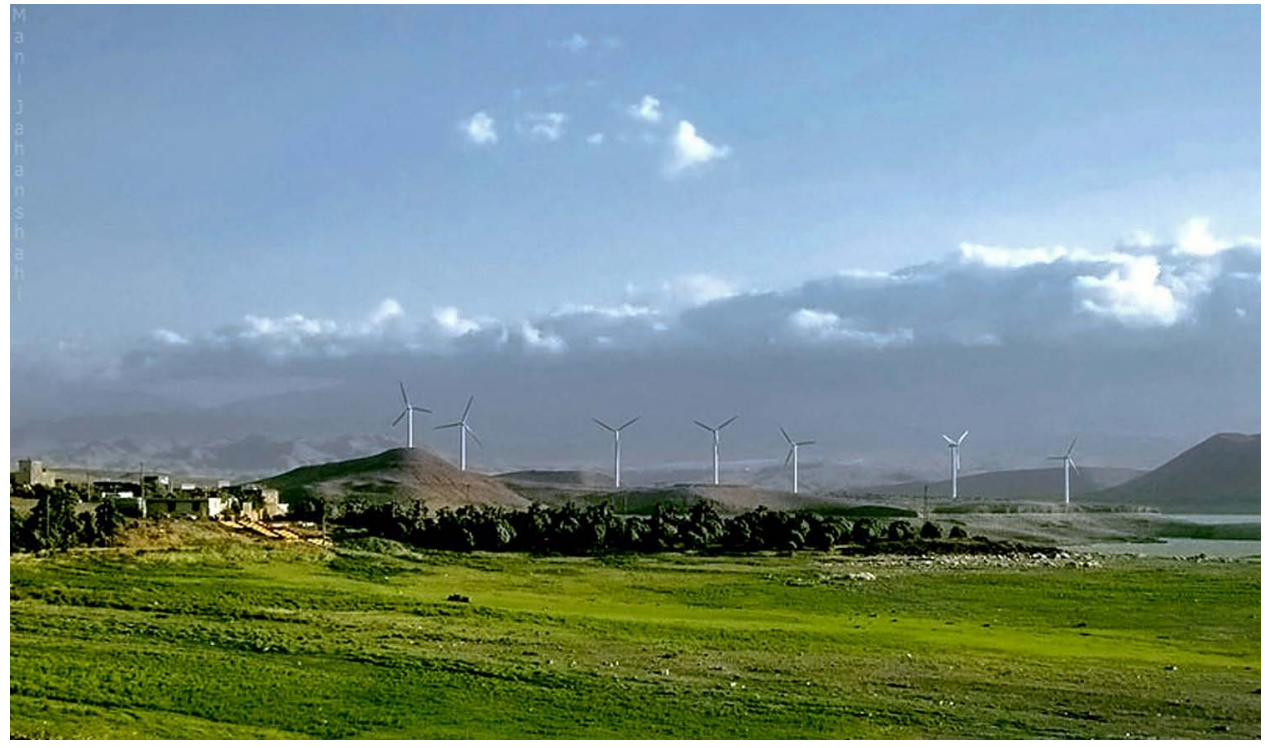

Figure 4. Manjil wind farm (Jahanshahi, 2008)

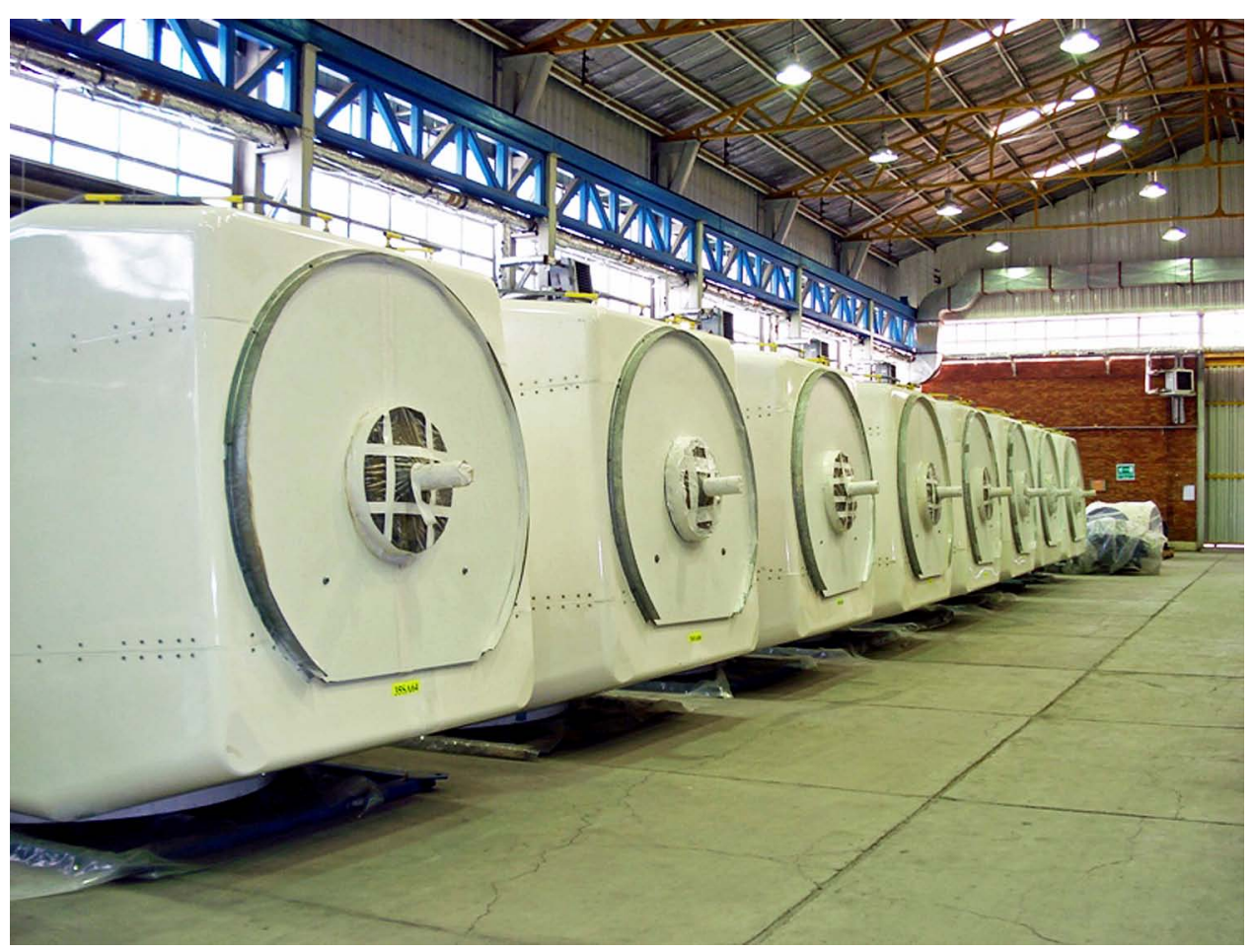

Figure 5. Turbines designed and manufactured in Tehran, Iran (Saba Niroo, 2008)

entertaining facilities; public transport; communications; neighbourhood satisfaction; social services; environment.

- Security (12 indicators): traffic safety; health safety; delinquency (public safety); financial security; family safety; social security; sexual security; nutrition security; judicial security; cultural security; environmental security; natural disasters.
- Participation (4 indicators): economic/environmental participation; political/managerial participation; social participation; cultural participation.

- Cultural homogeneity/diversity (5 indicators): cultural consumptions; cultural engagement; ethnic background; sense of belonging; similarity. 


\section{Offprint provided courtesy of www.icevirtuallibrary.com Author copy for personal use, not for distribution}

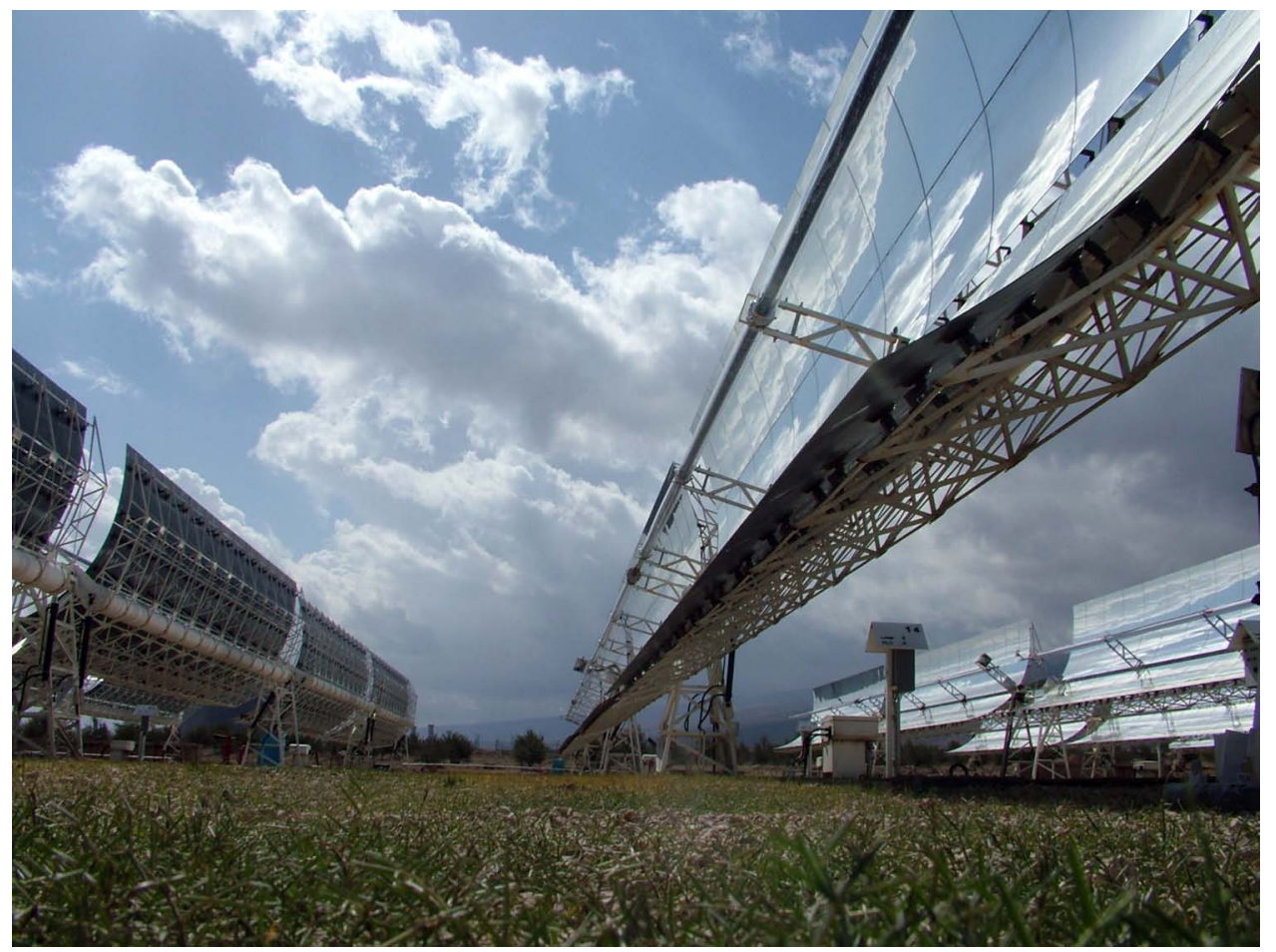

Figure 6. Shiraz solar power plant, Shiraz, Iran (Shiraz University,

2013)

To improve the energy and environmental performance of domestic building envelopes, IFCO developed the simulation software BCS19 in compliance with Code 19 of the national building regulations (IFCO, 2014). Code 19 defines the criteria and regulations for reducing energy consumption in public and private buildings. Its main topics include: external wall insulation; installation of doubleglazed windows with thermal brick, wooden or standard polyvinyl chloride (PVC) frames; insulation of air channels, pipe installations and hot water production systems; installation of local control systems such as thermostatic valves on radiators; the installation of weather compensators. BSC19, as an assessment tool, evaluates the energy performance of a building based on data regarding building elements and specifications and makes suggestions for future improvements. It should be noted that BCS19 is not compulsory in practice in Iran.

In this regard, the Urban Services Deputy of Tehran Municipality drew attention to urban sustainability by establishing the Office for Environment and Energy in 2003. This was expanded in 2006 and converted to the Office for Environment and Sustainable Development. This is one of the key departments involved in the evaluation of sustainable development in the urban context. The department evaluates the environmental impacts and energy performance of buildings owned by Tehran Municipality, and 39 environmental indicators have been determined within eight categories of

- improvement of environmental management

- controlling water and soil pollution
- purification of environmental pollutants

- environmental assessment of urban management projects

- controlling air, noise and light pollution

- energy efficiency and the development of renewable energies

- environmental education

- biodiversity management.

It is notable that Iran suffers from not having a cohesive strategic plan towards the development of urban sustainability assessment mechanisms. Some organisations and governmental departments that have been involved in developing social, economic and environmental indicators in recent years have dispersed and are now entirely separated from each other. There should be a way to bring all of them under one umbrella to enable a more comprehensive collaboration based on a participatory management system. Additionally, the data sources available considered fragmentary and scattered.

\section{Discussion}

\subsection{Policies and legislation for sustainable urban development}

Regarding sustainable development issues (air pollution, traffic congestion, building quality control, social disparity, economic welfare etc.), most Iranian cities suffer from a lack of effective urban management. It has been suggested that a restructuring of the distribution of power towards decentralisation of central government and empowerment of local authorities and 


\section{Offprint provided courtesy of www.icevirtuallibrary.com Author copy for personal use, not for distribution}

neighbourhood municipalities might be helpful in this regard (Tajbakhsh, 2004). Although many government departments and NGOs, including policy-makers, decision-makers, architects, urban planners, sociologists, economists and environmental experts, are making an effort to achieve some improvement, some city officials and stakeholders assert that Iranian cities require a more comprehensive strategy and governance settlement and a stronger and more democratic leadership (Madanipour, 2011).

One of the most important criteria of sustainable urban development is public participation in the decision-making process. In Europe, public participation in decision making and access to justice in environmental matters has been obligatory under an EU directive since 1998. In Iran, although the establishment of local advisory councils has been a great step towards public participation in decision making, the centralised nature of urban governance still remains a major issue in repressing sustainable development.

An element of ambiguity can be observed in sustainability regulations in Iran. Although, theoretically, the holistic urban agenda is defined according to sustainable development goals as specified in the fifth development plan, it is still questionable how these goals could make the built environment - on every scale, from a single building to a neighbourhood to a whole $\mathrm{n}$ urban area - socially, environmentally and economically sustainable. The UK, one of the most important pioneers of sustainable urban developments, has attempted to set up agendas for the implementation of a new generation of sustainable technologies in the building sector at national, regional and local levels. For example, to assess the energy performance of domestic buildings in the UK, energy performance certificates (EPCs) based on the Standard Assessment Procedure were introduced in 2007 within UK building regulations (Rydin, 2010). By 2016, all governmental building procurement projects will have to use design programmes based on building information modelling, which enables automatic assessment of building energy efficiency and the lifecycle cost of building elements (Ganah and John, 2014). Furthermore, the UK has recently set up an agenda for sustainable housing development to be achieved by 2016. All local council housing developments have to meet level 6 of the Code for sustainable homes, which is part of the Building Research Establishment environmental assessment method (Breeam) (Osmani and O'Reilly, 2009).

Iran urgently needs recognition of legislation for sustainable policies and their implementation. The installation of an EPC programme has been in progress since Shirzad Hasanbeigi, the secretary of energy in the National Standard and Industrial Research Organisation, announced EPC legislation and implementation in 2013 (ISNA, 2012). Also, to improve the energy efficiency of buildings in compliance with national building regulations in Iran, Code 19 was passed by the national parliament in 1991. Despite all efforts to revise the code 10 years after its first publication, it still lacks high levels of aims and objectives in addressing the characteristics of Iranian buildings and is not completely implemented in practice (Fayaz and Kari, 2009).
The complexity of the bureaucratic structure of urban management in Iran creates a vast gap between regulations and implementation. Despite efforts in both public and private sectors, some respected establishment figures and high-profile officials now warn of the devastating effects of current levels of market-based urban development. Since high profits do not necessarily imply efficiency, policy makers should strengthen the contribution of social and environmental matters to the planning process and decision-making procedures. Implementation of such policies and regulations is even more fundamental concerning the local conditions in Iran. Refining implementation methods and procedures and assessing and monitoring projects within all stages of design, construction and performance could significantly influence the current situation. What is comprehensively missing in Iranian urban management is independent powerful leadership.

\subsection{Sustainability assessment methods and technologies} There is a variety of schemes and ways of assessing the sustainability of buildings and developments for both new developments as well as buildings in use. In the UK, the Building Research Establishment (BRE) developed the pioneer of sustainability assessment systems, Breeam, in 1990 (Banihashemi Namini et al., 2013). Similar tools and systems in use elsewhere include Casbee (comprehensive assessment system for built environment efficiency) operated by the Japan Sustainable Building Consortium (JSBC), Leed (leadership in energy and environmental design) developed by the US Green Building Council, the green star system of the Green Building Council in Australia, the Canadian green globe model and HQE (haute qualite environmentale) certification in France (Rydin, 2010).

These tools and systems are being applied to evaluate the sustainability performance of different types of buildings and developments within the stages of design, construction and operation based on different criteria. For example, Breeam measures the sustainability of a variety of building types (industrial, offices, retail and housing, healthcare venues, courts, prisons and educational establishments) under ten different categories (Rydin, 2010). Projects assessed using Breeam are ranked as pass, good, very good or excellent. In 2009, Breeam expanded with the launch of Breeam Communities and is being adapted to assess the impacts of urban developments at the planning stage and to integrate with more strategic issues for planning at the neighbourhood level. Breeam In Use is being applied to evaluate the performance of existing non-domestic buildings. Some of the other assessment tools widely applied in western countries for community purposes at urban and regional levels are the environmental impact assessment, strategic environmental assessment, sustainability appraisal, quality of life indicators and the index of multiple deprivation.

At present, the only legislated sustainability assessment method implemented in the national construction industry of Iran is the EIA, which is compulsorily applied to the development of industrial buildings and some specific large-scale construction projects. So far, only Tehran Municipality has set up a sustainable development office to assess and monitor the energy performance of buildings, 


\section{Offprint provided courtesy of www.icevirtuallibrary.com} Author copy for personal use, not for distribution

and this is limited to only those buildings owned by the municipality. Many academics and researchers are now looking at urban and building sustainability evaluation, but most focus on theoretical studies rather than the development of practical assessment methods or tools. A lack of collaboration among academic, industrial practitioners and government in the research and development of sustainability assessment is also an issue in Iran.

That said, research implemented in 2013 by a group of experts introduced Satbir - a sustainability assessment tool for residential buildings in Iran - which, it is claimed, could address 'environmental phenomena from a managerial perspective' (Banihashemi Namini et al., 2013). Satbir covers five categories - resource management, quality management, zone management, environmental impacts management and risk management - and includes 49 indicators. Satbir tries to identify the role of project manager as the 'authorised assessor' through three phases of design, construction and operation. The tool was developed based on PMBok (project management body of knowledge) criteria. Satbir also takes into account issues regarding the social, economic and environmental aspects of sustainability. Satbir simplifies the scoring methods to reduce the workload and also facilitates the involvement of a project manager with minimum training. Prioritisation and weighting processes of the indicators were applied under local conditions through a questionnaire survey of 118 experts and scholars including architects, urban designers, and civil, electrical and mechanical engineers.

\subsection{Energy efficiency}

Despite the fact that Iran consumes less energy in comparison with most developed countries and some oil-based economies in the Middle East, energy consumption is a critical issue and the trends demonstrate a drastic increase in energy demand over recent decades: between 1990 and 2010, energy use per capita rose by 130\% (World Bank, 2011). According to data released by the Statistical Centre of Iran (SCI, 2013) total energy consumption per capita in 2011 was equivalent to $2222 \mathrm{~kg}$ of oil equivalent. Total energy use in the building sector (residential, public and commercial buildings) increased by about $16 \%$ within the 6 year period from 2005 to 2011 and, in the same period, there was an increase of about $25 \%$ in electricity and $41 \%$ in natural gas consumption in this sector (SCI, 2013). Natural gas accounts for about $73 \%$ of total energy consumption in the building sector, while electricity has a $12 \%$ stake and kerosene $8 \%$ of total energy use (SCI, 2012). Natural gas and electricity are the key energy carriers in the household sector while the proportion of other hydrocarbon carriers (e.g. gas oil, LPG, fuel oil, gasoline and coal) is relatively small (Farahmandpour et al., 2008). The average rate of electric power consumption per household is about $2679 \mathrm{kWh} /$ year (SCI, 2012) while natural gas use is $2080 \mathrm{~m}^{3} /$ year per household (Abbaspour et al., 2013). The highest proportion of energy consumed by households is allocated to appliances for heating, cooling and lighting (Abbaspour et al., 2013).

The key driving forces behind the ferociously growing trend of energy consumption in Iran are the oil-based economic expansion, considerable population growth in past decades and severely subsidised energy (12\% of GDP) (Moshiri, 2012). Such high incremental energy demand, particularly in the building sector, necessitates the recognition of methods for saving energy in building materials, construction systems and end-user behaviour. Effective utilisation of construction materials is one of the key factors in good thermal performance of a building envelope. In the $\mathrm{UK}$, insulated cavity walls or cladding walls are widely used for external walling. Such walls can achieve a $U$-value as low as $0 \cdot 2 \mathrm{~W} /$ $\mathrm{m}^{2} \mathrm{~K}$. Insulation is also installed in floors, roofs and any possible heat bridges. Typically, windows are double- or triple-glazed with timber or u-PVC frames with a $U$-value below $1 \cdot 5 \mathrm{~W} / \mathrm{m}^{2} \mathrm{~K}$. All these measures ensure that overall building/house envelopes have a very good energy efficiency profile. In Iran, although Code 19 mandates the installation of insulation in external walls and the employment of double-glazed timber/u-PVC frame windows, deficient implementation and reckless supervision has led to inefficient use. As mentioned earlier, HCBs are the most popular building material used for external walls in Iran; with a $U$-value of $1 \cdot 08-1 \cdot 30 \mathrm{~W} / \mathrm{m}^{2} \mathrm{~K}$, walls of this type have a $U$-value five to six times higher than the materials commonly used in the UK (Mohammad and Shea, 2013).

The IEEO, with its four main areas covering energy generation, energy consumption, planning and research, and smart networks, has committed itself to improving energy efficiency in industrial and building sectors in Iran. This has led to some pilot research projects in the country in the past few years. The large-scale project Faham (intelligent measuring and energy management system) was launched in 2011 with a budget of around 6000 billion Rial (£115 million). Faham is dedicated to installing automatic metering infrastructure for 3200000 industrial, commercial and residential buildings in four provinces of Iran (Sharifian Attar et al., 2012). The aim of the project is to decrease electricity losses by at least $1 \%$ per year and achieve a $14 \%$ decrease in overall network loss by 2015 (IEEO, 2013). Faham is not only a tool to capture the energy consumption of the building, but also a hardware and software architecture capable of capturing real-time consumption, demand, voltage, current and other information (IEEO, 2013).

A culture of reduced energy usage needs to be implemented through social and educational programmes. In Iran, energy is still cheap enough to be ignored. It is probable that most people think they live in a land of infinite 'black gold'. The management, control and improvement of a culture of reduced energy use would lead to a reduction in energy consumption. Energy-efficient buildings derived from architectural solutions should thus be coupled with changing users' behaviour in order to effectively improve energy efficiency in the building sector.

\subsection{Renewable energy}

In 2011, renewable energy contributed just $0 \cdot 61 \%$ to Iran's total primary energy consumption (Rezaei et al., 2013). The huge potential of renewable energy in Iran demands serious determination to redefine the proportion of renewable resources in the country's energy production. The government should consider the 


\section{Offprint provided courtesy of www.icevirtuallibrary.com Author copy for personal use, not for distribution}

implementation and development of clean energy infrastructure and technologies by encouraging and supporting the private sector. However, some argue that in the economic structure of Iran, which is heavily dependent on fossil fuels, the development of renewable energies would lead to a conflict of interests.

The Iran Renewable Energy Organization (Suna) has previously taken the initiative in proposing potential measurements for renewable energy development. According to Suna, the private sector has submitted a proposal for the generation of $3000 \mathrm{MW}$ from renewable energy industries; however, the needlessly timeconsuming process of contracting, insufficient funds, inadequate legislative support and institutional disfunctionality remain fundamental barriers to the development process (Rezaei et al., 2013). Alongside infrastructure development, it is necessary to think through this issue in order to improve the application of renewable energies in urban environments.

\section{Conclusion}

This paper has studied sustainable urban development in Iran by focusing on urban governance, sustainable technologies and assessment mechanisms based on Iranian national and local characteristics. In conclusion, it is potentially feasible to implement renewable energy technologies in Iran due to its geographical features, although a more efficient managerial system is needed. There is also substantial potential to improve the energy performance of buildings by considering energy-efficient design and technology and end-user behaviour with regard to energy consumption patterns. While avoiding bureaucratic procedures, the government needs to set up more detailed and practical legislation, regulations and guidance for sustainable urban development associated with more applicable assessment and monitoring procedures, methods and tools. Recognition and investigation of the sustainability features of the rich legacy of traditional Iranian architecture and planning can hopefully lead architects and planners to rethink sustainable design solutions and alternatives. Concerning the long-term history of Iran and its unique culture in the Middle East, sustainable urban development could also better preserve and promote its iconic historical urban and architectural characteristics.

Future economic growth alongside an improvement in people's quality of life in the light of potential broadening of a healthier and greener built environment should definitely encourage sustainable urban development in Iran. However, it is imperative that there should be a more democratic and powerful leadership body in the structure of Iranian urban management in order to achieve integrated and effective sustainable urban development based on monitored and measured data and comprehensive analysis and assessment. Blueprints regarding sustainable urban development in Iran have been delineated in many research projects and academic papers, but it has also been identified that there is a huge gap between academic circles and the authorities in sustainable urban development and environmental management. Dynamism is needed to push these research outcomes forward to gain the attention of relevant governmental organisations.

\section{REFERENCES}

Abbaspour M, Karbassi A, Khalaji Asadi M et al. (2013) Energy demand model of the household sector and its application in developing metropolitan cities (case study: Tehran). Polish Journal of Environmental Studies 22(2): 319-329.

Ahmadkhani Maleki B (2011) Traditional sustainable solutions in Iranian desert architecture to solve the energy problem. International Journal on Technical and Physical Problems of Engineering 3(6): 84-91.

Alizadeh A and Keshavarz A (2005) Status of agricultural water use in Iran. Water Conservation, Reuse, and Recycling: Proceedings of an Iranian-American Workshop. National Academies Press, Washington DC, USA, pp. 94-105.

Andalib A, Daneshpour A, Kazemian G, Zaker Haghighi K and Matavaf S (2010) Tehran New Detailed Plan (Approval 2007), Tehran Urban Development and Planning Department Reports (Report 2). See http://www.trudo.ir/tdrt_content/media/image/ 2013/10/2698_orig.pdf (accessed 11/05/2015) (in Persian).

AoTM (Atlas of Tehran Metropolis) (2014) Population Increase in Tehran Districts. See http://atlas.tehran.ir/Default.aspx? tabid=264 (accessed 18/10/2014).

Arjomand Kermani A and Luiten E (2009) Sustainable urban planning in Iran. Proceedings of SUE-MoT Conference, 2nd International Conference on Whole Life Urban Sustainability and its Assessment, Loughborough, UK, pp. 322-335.

Asadi Asad Abad M, Baghban Taraghdari M, Shirali M, Mohagheghzadeh F and Abdollahian H (2012) Development of biomass energy in Iran. International Journal of Advanced Scientific and Technical Research 1(2): 235-241.

Badri S and Eftekhari A (2003) Sustainability assessment: thoughts and methods. Geographic Research 18(2): 9-34 (in Persian).

Banihashemi Namini S, Shakouri M, Tahmasebi M and Preece C (2013) Managerial sustainability assessment tool for Iran's buildings. Proceedings of the Institution of Civil Engineers Engineering Sustainability 167(1): 12-23, http://dx.doi.org/10. 1680/ensu.12.00041.

CCSD (Cambridge Centre for Sustainable Development) (2014) Energy Efficiency in the Built Environment Research Programme. See http://www-csd.eng.cam.ac.uk/themes0/ energy-demand/energy (accessed 11/05/2015).

Devuyst D (2000) Linking impact assessment and sustainable development at the local level: the introduction of sustainability assessment systems. Sustainable Development 8(2): 67-78.

DoE (Department of Environment) (2013) The History of EIA Bureau. See http://www.doe.ir/Portal/home/?121164/\%D8\%AA \%D8\%A7\%D8\%B1\%DB\%8C\%D8\%AE\%DA\%86\%D9\%87\% 20\%D8\%AF\%D9\%81\%D8\%AA\%D8\%B1\%20\%D8\%A7\% D8\%B1\%D8\%B2\%DB\%8C\%D8\%A7\%D8\%A8\%DB\%8C\% 20\%D8\%B2\%DB\%8C\%D8\%B3\%D8\%AA\%20\%D9\%85\% D8\%AD\%DB\%8C\%D8\%B7\%DB\%8C (accessed 11/05/2015) (in Persian).

DoE (2014) National Committee of Sustainable Development. See www.doe.ir (accessed 11/05/2015) (in Persian).

Eiraji J and Akbari Namdar S (2011) Sustainable systems in Iranian traditional architecture. International Conference on Green 
Buildings and Sustainable Cities, Bologna, Italy, Procedia Engineering 21: 553-559.

Farahmandpour B, Nasseri I and Jafari H (2008) Analysis of ultimate energy consumption by sector in Islamic Republic of Iran. Proceedings of 3rd IASME/WSEAS International Conference on Energy \& Environment, Cambridge, UK, pp. 151-157.

Fayaz R and Kari BM (2009) Comparison of energy conservation building codes of Iran, Turkey, Germany, China, ISO 9164 and EN 832. Applied Energy 86(10): 1949-1955.

Firouz C (2010) Iran Revives Planning Agency to Enact Economic Reforms. See http://www.al-monitor.com/pulse/fr/originals/ 2013/08/iran-planning-agency-revived-rouhani.html\# (accessed 18/10/2014).

Fotouhi M (1995) Geothermal development in Sabalan, Iran. Proceedings of World Geothermal Congress, Florence, Italy, pp. 191-196.

Fotouhi M and Noorollahi Y (2000) Updated geothermal activities in Iran. Proceedings of World Geothermal Congress, Kyushu-Tohoku, Japan, pp. 183-185.

Foy C (2001) The Iran Project: About Iran. See http://www. iranproject.org/iran/iran.html (accessed 11/05/2015).

Ganah A and John G (2014) Achieving level 2 BIM by 2016 in the UK. In Computing in Civil and Building Engineering (Issa R and Flood I (eds)). ASCE, Orlando, FL, pp. 143-150.

Hafeznia M and Veicy H (2009) Consideration of local sub-councils in optimum urban governance, case study: local sub-councils of Tehran. Proceedings of 4th International Conference of the International Forum on Urbanism (IFoU), The New Urban Question - Urbanism beyond Neo-Liberalism, Amsterdam, the Netherlands, pp. 1225-1228.

IEEO (2013) FAHAM. See http://www.iransg.com/en/home (accessed 11/05/2015).

IFCO (Iranian Fuel Conservation Company) (2014) Energy Conservation is an International Responsibility. See http://www.ifco.ir/english/index.asp (accessed 11/05/2015).

ISNA (Iranian Students' News Agency) (2012) The implementation of EPC for buildings from 2013 (in Persian). See http://isna.ir/ fa/print $/ 0000232943 / \%$ D8\%B7\%D8\%B1\%D8\%AD-\%D8\% A8\%D8\%B1\%DA\%86\%D8\%B3\%D8\%A8-\%D8\%A7\%D9\% 86\%D8\%B1\%DA\%98\%DB\%8C-\%D8\%B3\%D8\%A7\%D8\% AE\%D8\%AA\%D9\%85\%D8\%A7\%D9\%86-\%D9\%87\%D8\% A7-\%D8\%A7\%D8\%B2\%D8\%B3\%D8\%A7\%D9\%84-\%D8\% A2\%DB\%8C\%D9\%86\%D8\%AF\%D9\%87-\%D8\%A7\%D8\% AC\%D8\%B1\%D8\%A7\%DB\%8C\%DB\%8C (accessed 09/06/ 2015)

Jahanshahi M (2008) Manjil Wind Farm. See http://www.pbase. com/manibj/image/70993267 (accessed 11/05/2015).

Kazemi Karegar H, Zahedi A, Ohis V, Taleghani G and Khalaji M (2005) Wind and Solar Energy Developments in Iran. University of Tehran, Tehran, Iran.

Khosravi M (1987) Methodology for the Assessment of Environmental Factors in Project Development. Department of Environment, Tehran, Iran.
Latifian B, Jasemi A and Bandari M (2014) Environmental accounting and sustainability report. International Research Journal of Applied and Basic Sciences 8(3): 325-328.

Madani K (2014) Water management in Iran: what is causing the looming crisis? Journal of Environmental Studies and Sciences 4(4): 315-328, http://dx.doi.org/10.1007/s13412-014-0182-z.

Madanipour A (2006) Urban planning and development in Tehran. Cities 23(6): 433-438.

Madanipour A (2011) Sustainable development, urban form and megacity governance and planning in Tehran. In Megacities; Urban Form, Governance and Sustainability (Sorensen A and Okata J (eds)). Springer, New York, NY, USA, pp. 67-91.

MoE (Ministry of Energy) (2008) Iran's Energy Balance Report 2006. See http://pep.moe.gov.ir/getattachment/0900cf75-48e64e48-919a-d5f7d9a6973b/\%D8\%AA\%D8\%B1\%D8\%A7\% D8\%B2\%D9\%86\%D8\%A7\%D9\%85\%D9\%87-\%DA\%A9\% D9\%84-\%DA\%A9\%D8\%B4\%D9\%88\%D8\%B1-\%D8\%B3\% D8\%A7\%D9\%84-1385.aspx (accessed 12/10/2014) (in Persian).

Mohammad S and Shea A (2013) Performance evaluation of modern building thermal envelope designs in the semi-arid continental climate of Tehran. Buildings 3(4): 674-688.

Mol (Ministry of Interior) (2010) The Municipality Establishment. See http://www.moi.ir/Portal/Home/Default.aspx? CategoryID=3046571a-7275-4160-81a1-3d66bbb3410c (accessed 18/10/2014) (in Persian).

Moshiri S (2012) Energy price reform and energy efficiency in Iran. Proceedings of IAEE International Conference, Perth, Australia, pp. 33-37.

Mulvaney D (2011) Green Politics: An A-to-Z Guide. SAGE Publications, Los Angeles, USA.

Nanbakhsh H (1993) Environmental Impact Assessment of Potable Water Supply and Sanitation in Rural Areas of Developing Countries. PhD thesis, University of Salford, Salford, UK.

Nasrollahi F (2009a) Climate and Energy Responsive Housing in Continental Climates: The Suitability of Passive Houses for Iran's Dry and Cold Climate. Universitätsverlag der TU Berlin, Berlin, Germany.

Nasrollahi F (2009b) Energy efficient architecture for Tehran. Proceedings of IFHP World Congress 2009, Urban Technology for Urban Sustainability: Climate Change and Energy Efficiency, Berlin, Germany.

Nasrollahi F, Wehage P, Effatolsadat Shahriari E and Tarkashvand A (2013) Energy Efficient Housing for Iran-Pilot Buildings in Hashtgerd New Town. Universitätsverlag der TU Berlin, Berlin, Germany, Young Cities research paper series, vol. 04.

NematiMehr M (2008) Architecture, urban design and environmental sustainability, case study: Iranian arid old cities. International Journal of Environmental, Cultural, Economic and Social Sustainability 4(1): 139-146.

Noorollahi Y, Yousefi H, Itoi R and Ehara S (2009) Geothermal energy resources and development in Iran. Renewable and Sustainable Energy Reviews 13(5): 1127-1132.

Osmani M and O'Reilly A (2009) Feasibility of zero carbon homes in England by 2016: a house builder's perspective. Building and Environment 44(9): 1917-1924. 


\section{Offprint provided courtesy of www.icevirtuallibrary.com Author copy for personal use, not for distribution}

Owens S (1991) Energy-conscious Planning: The Case for Action. CPRE, London, UK.

Rahbar D (2005) Iran's effort for progressive of EIA in a transboundary context. Proceedings of 8th Meeting of the Working Group of EIA Convention, Geneva, Switzerland. April 25-27, 2005. See http://www.unece.org/fileadmin/DAM/ env/eia/documents/WG8_april2005/Iranian\%20EIA\% 20system.pdf (accessed 08/10/2014).

Rezaei M, Chaharsooghi SK and Abbaszadeh P (2013) The role of renewable energies in sustainable development: case study Iran. Iranica Journal of Energy and Environment 4(4): 320-329.

Rezazadeh R (2011) Women empowerment and good urban governance in Iran. Asian Social Science 7(3): 260-268.

Rydin Y (2010) Governing for Sustainable Urban Development. Earthscan, London, UK.

SABA (2010) Iran Energy Balances Report. See http://www.saba. org.ir/saba_content/media/image/2012/04/3550_orig.pdf (accessed 11/05/2015) (in Persian).

Saba Niroo (2008) Turbines designed and manufactured in Tehran, Iran. See http://www.sabaniroo.co.ir/news/admin/sabaniroo/07. JPG (accessed 09/06/2015).

Sabetghadam M (2006) Energy and Sustainable Development in Iran. Helio International, Paris, France, Sustainable Energy Watch Report.

SCI (Statistical Centre of Iran) (2012) Iran Energy Statistics. See http://www.amar.org.ir/Default.aspx?tabid=494 (accessed 11/05/2015).

SCI (2013) Atlas of Selected Results of the 2011 National Population and Housing Census. See https://www.amar.org.ir/Default.aspx? tabid=133 (accessed 11/05/2015).

Sharifi M and Shabanikia A (2012) Report of Renewable Energy Organization of Iran. Renewable Energy Research and Technology Bureau, Pendar-e Nik Publishing, Tehran, Iran (in Persian).

Sharifian Attar T, Seyyed Mahdavi S, Saebi J and JavidI MH (2012) Implementation of smart transmission grid in Iran (case study: Khorasan Regional Electricity Company). Proceedings of 20th Iranian Conference on Electrical Engineering (ICEE), Tehran, Iran, pp. 422-426.

Shiraz University (2013) Shiraz Solar Power Plant. See http://www. shirazu.ac.ir/index.php?page_id $=4098 \&$ search_words=no (accessed 11/05/2015).

Soflaee F and Shokouhian M (2005) Natural cooling systems in sustainable traditional architecture of Iran. Proceedings of International Conference on Passive and Low Energy Cooling for the Built Environment, Santorini, Greece, pp. 715-719.

Suna (Iran Renewable Energy Organization) (2012a) Biomass Energy. See http://www.suna.org.ir/suna_content/media/image/ 2012/10/1734_orig.pdf (accessed 11/05/2015) (in Persian).

Suna (2012b) History \& Objectives of Iran Renewable Energy Organization (SUNA). See http://www.suna.org.ir/en/home (accessed 18/10/2014).

Tabari H, Abghari H and Hosseinzadeh Talaee P (2012) Temporal trends and spatial characteristics of drought and rainfall in arid and semiarid regions of Iran. Hydrological Processes 26(22): 3351-3361.
Tabatabaei SJ, Eskandari H and Aghaei Y (2013) The effect of materials type and form of the roof on the thermal efficiency of buildings in hot and dry climates. Gazi Univertesi Gazi Egitim Fakultesi Dergisi 4(3): 1-8. See http://www.gugef.com/v4n3. html (accessed 12/06/2015).

Taghavi Jeloudar M, Han M, Davoudi M and Kim M (2013) Review of ancient wisdom of Qanat, and suggestions for future water management. Environmental Engineering Research 18(2): 57-63.

Tajbakhsh K (2005) Planning culture in Iran: centralization and decentralization and local governance in the twentieth century (the case for urban management and planning). In Comparative Planning Cultures (Sanyal B. (ed.)). Routledge, NY, USA, pp. 67-90.

Tavassoli M (2011) The Art of Renewing Urban Structure with Four Case Studies, 2nd edn. Mahmoud Tavassoli Publication Tehran, Iran (in Farsi).

Tehran Municipality (2007) Green Workbook. Environment and Sustainable Development Task Force, Tehran, Iran (in Persian).

Tehran Municipality (2013) ATAF Executive Instructions: Departments, Organizations and 22 Municipal Districts in Tehran. See http://ataf.tehran.ir/Portals/0/guidelines1111.pdf (accessed 12/05/2015).

Tehran Municipality (2014) History of City Councils. See http://en. tehran.ir/Default.aspx?tabid=90 (accessed 18/10/2014).

UN (United Nations Department of Economic and Social Affairs) (2014) World Urbanization Prospects. See http://esa.un.org/ unpd/wup/Highlights/WUP2014-Highlights.pdf (accessed 12/05/2015).

Vahdat Zad V (2011) Spatial discrimination in Tehran's modern urban planning 1906-1979. Journal of Planning History 12(1): 49-62.

World Bank (2011) Energy Use ( $k g$ of oil equivalent per capita). See http://data.worldbank.org/indicator/EG.USE.PCAP.KG. OE? page $=6($ accessed 12/05/2015).

WWEA (World Wind Energy Association) (2014) 2014 Half-Year Report. See http://www.wwindea.org/webimages/WWEA_half_ year_report_2014.pdf (accessed 12/05/2015).

\section{WHAT DO YOU THINK?}

To discuss this paper, please submit up to 500 words to the editor at journals@ice.org.uk. Your contribution will be forwarded to the author(s) for a reply and, if considered appropriate by the editorial panel, will be published as a discussion in a future issue of the journal.

Proceedings journals rely entirely on contributions sent in by civil engineering professionals, academics and students. Papers should be 2000-5000 words long (briefing papers should be 1000-2000 words long), with adequate illustrations and references. You can submit your paper online via www.icevirtuallibrary.com/content/journals, where you will also find detailed author guidelines. 